\title{
Hexapod decomposers of Serra de Santa Catarina, Paraíba, Brazil: an area with high potential for conservation of Caatinga biodiversity
}

\author{
Matilde Vasconcelos Ernesto ${ }^{I}$, Carolina Nunes Liberal, Aila Soares Ferreira ${ }^{1}$, Ana Claudia Firmino Alves ${ }^{I}$, \\ Douglas Zeppelini' ${ }^{2}$ Celso Feitosa Martins ${ }^{1}$, Alessandre Pereira-Colavite ${ }^{1}$, Antônio José Creão-Duarte ${ }^{1}$, \\ Alexandre Vasconcellos ${ }^{1 *}$ \\ ${ }^{1}$ Universidade Federal da Paraíba Campus I, Departamento de Sistemática e Ecologia, João Pessoa, PB, \\ Brasil \\ ${ }^{2}$ Universidade Estadual da Paraíba Campus V, Departamento de Biologia, Centro de Ciências Biológicas e \\ Sociais Aplicadas, João Pessoa-PB, Brasil \\ *Corresponding author: Alexandre Vasconcellos, e-mail: alextermites@gmail.com
}

ERNESTO, M. V., LIBERAL, C. N., FERREIRA, A. S., AlVES, A. C. F., ZEPPELINI, D., MARTINS, C. F., PEREIRA-COLAVITE, A., CREÃO-DUARTE, A. J., VASCONCELLOS, A. Hexapod decomposers of Serra de Santa Catarina, Paraíba, Brazil: an area with high potential for conservation of Caatinga biodiversity. Biota Neotropica. 18(2): e20170410. http://dx.doi.org/10.1590/1676-0611-BN-2017-0410

\begin{abstract}
In detritus-based trophic systems, springtails, dung beetles, saprophagous calyptrate flies and termites consume and fragment organic matter and control populations of decomposer microorganisms, exerting a strong influence on energy and nutrient fluxes. A faunal inventory of these four groups of hexapods was performed in Serra de Santa Catarina (SSC), an area of arboreal-shrub caatinga located in the state of Paraíba, with the purpose of characterizing the assemblages of these taxa, and highlighting their unique links to the local ecosystem. Samplings were performed in May, 2014, and April, 2015, both during the rainy season. Standard sampling protocols for biodiversity inventory of the various taxa were used, including both active and passive sampling methods. In general, 114 species of hexapods were captured, with 26 species of springtails, 20 dung beetles, 30 saprophagous calyptrate flies and 38 termites, with sampling sufficiency varying from 69.5 to $96.8 \%$ of total estimated richness. Species richness of the groups are among the highest recorded for a single area of Caatinga, with some taxa being recorded for the first time for the domain. Several morphospecies had indeterminate taxonomic status, especially springtails and termites, and are quite likely new species to science. The structure of the assemblages of springtails, dung beetles, saprophagous calyptrate flies and termites recorded in SSC, suggest that this conserved area is unique within the highly impacted landscape of Caatinga, and has great potential for the conservation of biodiversity of this domain in the Northeast Region of Brazil.
\end{abstract}

Keywords: Coleoptera, Collembola, Diptera, Isoptera, Seasonally Dry Tropical Forests, Semiarid.

\section{Hexápodes decompositores da Serra de Santa Catarina, Paraíba, Brasil: uma área com elevado potencial para a conservação da biodiversidade da caatinga}

Resumo: No sistema trófico baseado em detritos, os colêmbolos, besouros escarabeíneos, moscas saprófagas e térmitas atuam no consumo e fragmentação da matéria orgânica e no controle das populações de microrganismos decompositores, exercendo forte influência nos fluxos de energia e nutrientes. Um inventário faunístico desses quatro grupos de hexápodes foi realizado na Serra de Santa Catarina (SSC), uma área de Caatinga arbóreo-arbustiva localizada no Estado da Paraiba, com intuito de caracterizar as taxocenoses desses táxons, salientando as suas peculiaridades ligadas ao ecossistema local. As coletas foram realizadas em maio/2014 e abril/2015, durante o período chuvoso na região. De acordo com o táxon, foram utilizados protocolos amostrais padronizados para inventários de biodiversidade, com métodos passivos e ativos de coleta. No geral, 114 espécies de hexápodes foram capturadas, sendo 26 de colêmbolos, 20 de besouros escarabeíneos, 30 de dípteros e 38 de térmitas, com suficiência 
amostral variando de 69,5 a $96.8 \%$ da total estimada. A riqueza de espécies por grupo está entre as maiores para uma única área de Caatinga, com alguns táxons sendo registrados pela primeira vez para o domínio. Especialmente para os colêmbolos e térmitas, várias morfoespécies tiveram seus status taxonômicos indeterminados, havendo elevada possibilidade de serem nova para a ciência. As estruturas e funcionalidades das taxocenoses de colêmbolos, besouros escarabeíneos, moscas saprófagas e térmitas registradas na SSC, sugerem que esse ecossistema é singular, dentro de um cenário generalizado de impacto antrópico presente na Caatinga, e possui um elevado potencial para a conservação da biodiversidade desse domínio no nordeste brasileiro.

Palavras-chave: Coleoptera, Collembola, Diptera, Florestas Tropicais Sazonalmente Secas, Isoptera, Semiárido.

\section{Introduction}

Hexapods comprise a large group of Arthropoda and represent significant evolutionary success as indicated by their great diversity among ecosystems of the world. The subphylum Hexapoda is divided into two taxa: Entognatha (Collembola, Protura and Diplura) and Insecta (Brusca \& Brusca 2013). These groups perform several fundamental processes for terrestrial ecosystems, especially in the tropics, such as nutrient cycling, soil aeration, energy flux, pollination and seed dispersal (Gullan \& Cranston 2008).

Detritus-based trophic systems contain several invertebrate groups that consume and fragment organic matter and control populations of decomposing microorganisms, among which springtails, dung beetles, saprophagous calyptrate flies and termites stand out (Coleman et al. 2004, Lavelle \& Spain 2005). Springtails are among the most abundant representatives of soil fauna (Cassagne et al. 2003), with more than 8,000 described species (Bellinger et al. 1996-2017). Dung beetles (Scarabaeidae sensu stricto) represent an important component of tropical ecosystems with more than 6,200 described species (Tarasov \& Génier 2015). The saprophagous calyptrate flies, families Calliphoridae, Sarcophagidae, Muscidae and Fanniidae, are notable for their role in the decomposition of organic matter of animal origin (Cornaby 1974); these families together account for about 9,000 described species distributed throughout the world (Carvalho et al. 2012). Lastly, termites account for high amounts of biomass in tropical regions, especially between the tropics of Cancer and Capricorn, with approximately 3,000 described species throughout the world (Vasconcellos 2010, Krishna et al. 2013).

The Caatinga domain is a mosaic of thorny shrub land and dry forests located in the semiarid region of northeastern Brazil (Leal et al. 2005), and composes the largest continuous complex of Seasonally Dry Tropical Forests (Särkinen et al. 2015). The biodiversity of the Caatinga has always been stigmatized as being poor and with low levels of endemism, but over the last decade this thinking has progressively changed (Santos et al. 2011, Bravo \& Calor 2014). Even with many areas not yet well known to science, the Caatinga has been subjected to heavy anthropic pressure, especially related to the removal of plant biomass and unbridled hunting of vertebrates (Leal et al. 2005, Portillo-Quintero \& Sánchez-Azofeifa 2010, Santos et al. 2011).

Studies on hexapod biodiversity can generate a rich database that can support conservation actions, both locally and regionally. According to Leivas \& Carneiro (2012), hexapods can serve as informative indicators of habitat quality because they exhibit relative sedentarism, are easily sampled, perform wide range of ecological functions, influence primary and secondary productivity of terrestrial ecosystems, exhibit microhabitat fidelity and possess short life cycles. The present study undertook a faunal inventory of four selected groups of hexapod decomposers (springtails, dung beetles, saprophagous calyptrate flies and termites) in Serra de Santa Catarina (SSC), an unique area of arboreal-shrub Caatinga with high potential value for conservation of the biodiversity of this domain in the state of Paraíba, in order to characterize their assemblages, and highlighting their peculiarities associated with the local ecosystem.

\section{Material and Methods}

\section{Study area}

Serra de Santa Catarina (SSC) is located in the caatinga region of the state of Paraíba (centered approximately at $7^{\circ} 00^{\prime} 46^{\prime \prime} \mathrm{S}, 38^{\circ} 11^{\prime} 12^{\prime \prime} \mathrm{W}$ ) (Figure 1), and extends for approximately $25 \mathrm{~km}$ encompassing an area of approximately $112.1 \mathrm{~km}^{2}$, from the Olho d'água do Frade (municipality of Nazarezinho) to the stream Saco dos Bois (São José da Lagoa Tapada) (Brandão et al. 2009), reaching elevations of over $830 \mathrm{~m}$ at some points (Sousa 2011). The area contains one of the few patches with arboreal formation in the Caatinga dominion in the state of Paraíba, but has undergone intense degradation with the withdrawal of vegetal biomass and illegal hunting. The predominant soil type is Litholic Neosol and there is a vegetative gradient of caatinga from shrubby, to arboreal-shrubby, to arboreal to forest patches, along the elevational gradient. Its phytogeographic system is classified as seasonal deciduous caatinga forest, forested savanna steppe and forest (IBGE 2012).

The climate is As (dry tropical) according to the Köppen classification (Alvares et al. 2013), with seven to eight dry months and irregular annual precipitation. The mean annual temperature of the area is $24.3^{\circ} \mathrm{C}$ with an average annual rainfall of $892 \mathrm{~mm}$, according to data obtained from WorldClim with a resolution of 30 arc-seconds (http:// www.worldclim.org).

\section{Faunistic Inventory}

Samplings were made in May, 2014, and April, 2015, during the rainy period of the region. Standardized biodiversity sampling protocols for each specific taxa were used. Specimens of springtails, dung beetles, saprophagous calyptrate flies were collected passively with traps. Active collections were employed for termite and also springtails. Ten points separated by at least $100 \mathrm{~m}$ were randomly selected for passive sampling. Sets of traps were installed at each point for collecting springtails, dung beetles, saprophagous calyptrate flies, which were exposed for $48 \mathrm{~h}$. Termites were sampled through active searches along six $65 \times 2$ $\mathrm{m}$ transects each with five $5 \times 2 \mathrm{~m}$ plots spaced at $10 \mathrm{~m}$. Transects were distributed with a minimum distance of $50 \mathrm{~m}$ from the border of the area and between transects. 

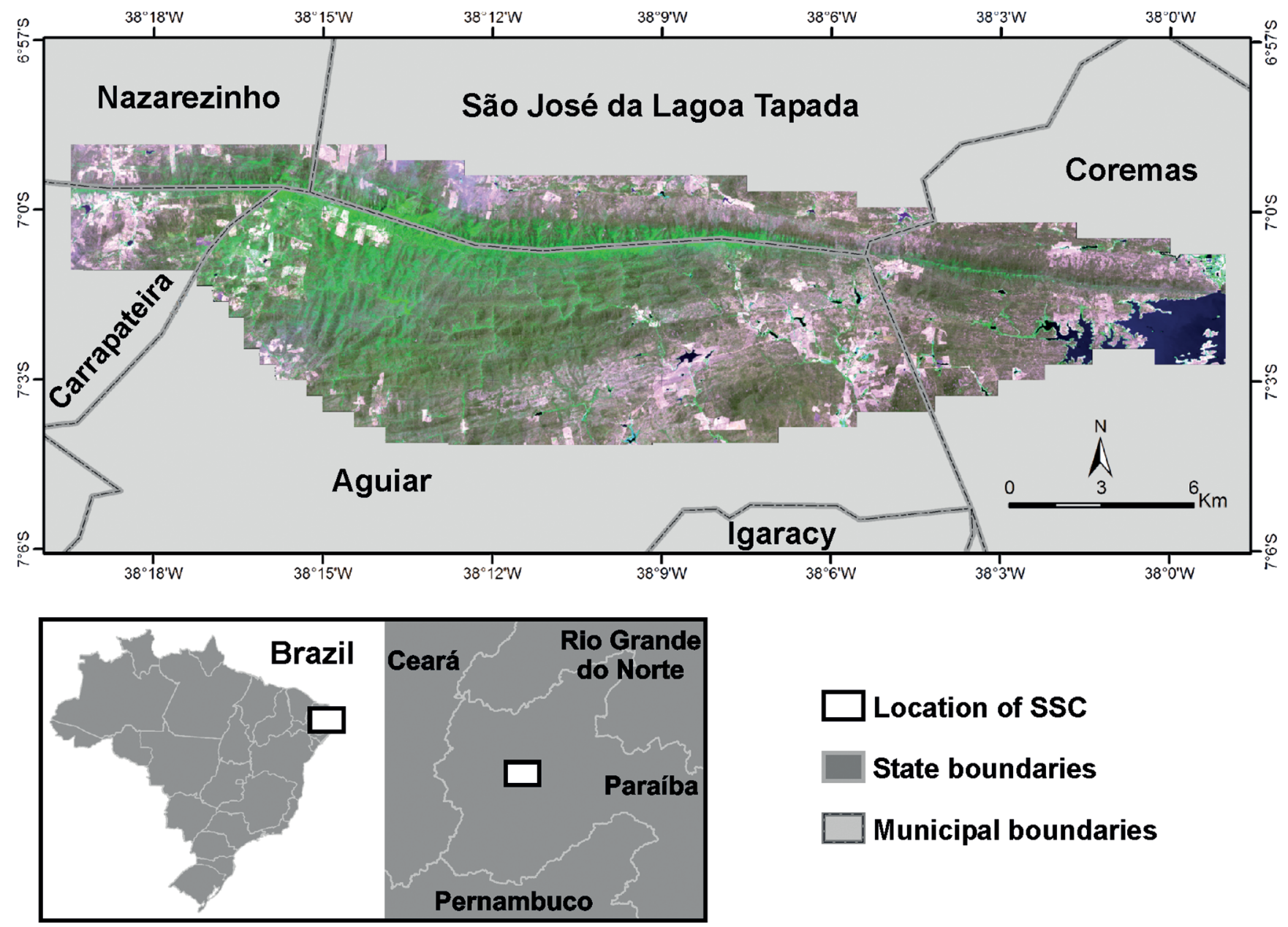

Location of SSC

State boundaries

Municipal boundaries

Figure 1. Location of Serra de Santa Catarina, Paraiba State, NE, Brazil.

\subsection{Springtails}

For sampling springtails, five pitfalls (diameter $11 \mathrm{~cm}$, height $7 \mathrm{~cm}$ ) were installed at each sampling point arranged in a cross and separated from each other by $1 \mathrm{~m}$ (Figure $2 \mathrm{~A}$ ). No bait was used and $70 \%$ alcohol was added to fix specimens. A Styrofoam disc was placed about $15 \mathrm{~cm}$ above the soil surface over each trap to protect against direct sunlight, litter fall and rain. A $30 \mathrm{~min} /$ person active search was performed at each point using an entomological aspirator. A Winkler extractor was also used to collect springtails in $1 \mathrm{~m}^{2}$ of litter per point, remaining active for six days (Querner \& Bruckner 2010). Sampling material was deposited in the Universidade Estadual da Paraíba (UEPB)

\subsection{Dung beetles}

Dung beetles were collected at each point with an array of four pitfalls (diameter $9.5 \mathrm{~cm}$, height $20 \mathrm{~cm}$ ) arranged in a square. Each array was composed of two traps baited with human feces (Figure 2C) and two with meat (rotten bovine spleen) (Figure 2D), distributed alternately in each of the vertices of the square array and separated by 3 $\mathrm{m}$ from each other. These are common baiting for dung beetles (Favila \& Halffter 1997, Milhomen et al. 2003). Originally with coprophagous habits, South American dung beetles diversified their diet after the extinction of mammal megafauna in the Pleistocene epoch, resulting in reduction of dung supply and increasing availability of carcasses as substrate, leading to new feeding habits, like necrophagy (Halffter \& Edmonds 1982; Halffer 1991).

Styrofoam discs were placed over the traps. After $48 \mathrm{~h}$ of exposure, trapped specimens were transferred to properly labeled containers containing $70 \%$ alcohol. The collected material was deposited in the Universidade Federal da Paraíba (UFPB).

\subsection{Saprophagous calyptrate flies}

Saprophagous calyptrate flies were collected at each point using a set of four traps (Figure 2E), separated by at least $10 \mathrm{~m}$ from each other. Although most of these flies have necrophagous habits (Souza \& Linhares 1997), some synatropic species are attracted by human feces and decaying organic vegetable matter (Carvalho et al. 2002), assuming coprophagous and saprophagous habits. To sampling all calyptratae Diptera in the study areas (Souza \& Linhares 1997; Carvalho et al. 2002), the traps were baited with about $100 \mathrm{~g}$ of four types of lure (Figure 2B): decaying sardine, meat (bovine spleen) and banana, and human feces. At the end of exposure, the collected dipterans were placed in a killing jar containing cotton soaked in ethyl acetate, and then transferred to properly labeled containers with $70 \%$ alcohol. The collected material was deposited in the Universidade Federal da Paraíba (UFPB). 

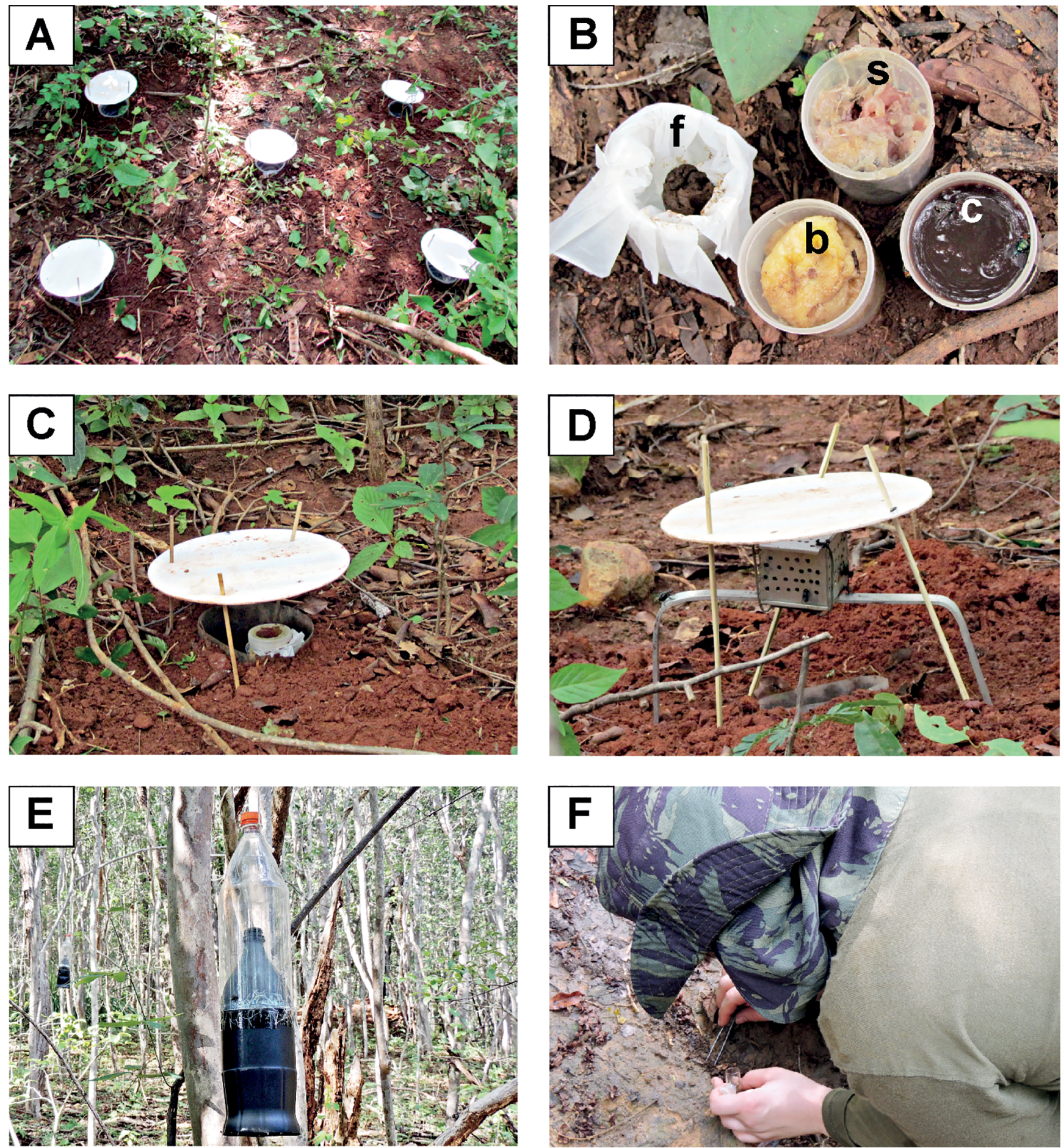

Figure 2. Sampling methods for sampling the diversity of springtails, dung beetles, saprophagous calyptrate flies and termites, in May, 2014, and April, 2015, in Serra de Santa Catarina, state of Paraíba, Brazil. A. Arrangement of pitfalls for collecting species of springtails; B. Baits: feces (f), sardines (s), banana (b) and bovine spleen (c); C. pitfalls baited with feces installed for collecting dung beetles; D. pitfalls baited with bovine spleen installed for collecting dung beetles; E. Traps for capturing saprophagous calyptrate flies installed in the field; F. Active search for termites in a $10-\mathrm{m}^{2}$ plot. 


\subsection{Termites}

Termites were sampled from thirty $5 \times 2 \mathrm{~m}$ plots for a total of 300 $\mathrm{m}^{2}$ each year (Cancello et al. 2002). Plots were sampled for $1 \mathrm{~h} \mathrm{x}$ person, during which termites were sought in active and abandoned nests, tunnels, live and dead tree trunks, foliage, inside and under fallen branches, in the ground, under rocks and in dead roots (Figure 2F). Sub-samples, mainly soldiers, were collected from colonies found in the plots. Samples were preserved in $80 \%$ alcohol. The species were categorized into food groups according to Vasconcellos et al. (2010), Vasconcellos \& Moura (2014) and from in situ observations of feeding habits. The collected material was deposited in the Universidade Federal da Paraíba (UFPB).

\section{Analyses}

Species accumulation curves and estimates of species richness were obtained using EstimateS 9.1.0 software (Colwell 2016), with 1,000 randomizations without replacement. In the case of termites, the frequency of occurrence of encounters in the plots was treated as an indirect measure of relative abundance. One-way analysis of variance was performed to compare the species richness and abundance according to the bait type. The data were analyzed using Statistica 8.0 (Statsoft 2007). The assumptions of ANOVA were tested.

\section{Results}

A total of 114 species of hexapods were captured, with 26 species of springtails, 20 dung beetles, 30 saprophagous calyptrate flies and 38 termites (Tables 1, 2, 3 and 4). The numbers of individuals were 2,326 of springtails, 1,303 of dung beetles and 7,669 saprophagous calyptrate flies. There were 287 encounters with termites in the plots.

\section{Springtails}

A total of 26 species of springtails were collected representing 11 families and 17 genera (Table 1). The family Entomobryidae had the greatest richness with eight species, four of which were new to science. Seira and Lepidocyrtus were the richest genera with five and three species, respectively. The species gen.n.1 of the family Bourletiellidae was the most abundant, with 493 individuals, followed by Sphaeridia sp., with 466 individuals. According to the mean estimated species richness, $96.83 \%$ of the species of Collembola at SSC were sampled (Sobs=26; Sest mean=26.85) (Figure 3).

\section{Dung beetles}

A total 1,303 dung beetles were recorded of 20 species distributed among eight genera (Table 2). The genera with the greatest species richness were Canthon (eight species) and Deltochilum (four species). The most abundant species was Canthon chalybaeus $(\mathrm{N}=674)$. Two other species of this genus, C. mutabilis and C. simulans, as well as the genus Eutrichillum, represented by E. hirsutum, were recorded for the first time in the Caatinga. It was estimated that $89.89 \%$ of the species of beetles at SSC were sampled (Sobs=20; Sest mean=22.25) (Figure $3)$. No significant difference was found in dung beetles abundance $(\mathrm{F}=0.12327$; d.f. $=1 ; 38 ; \mathrm{p}=0.73)$ and species richness $(\mathrm{F}=3.2208$;
Table 1. Springtails collected during the rainy period (May, 2014, and April, 2015) in Serra de Santa Catarina, state of Paraíba, Brazil.

\begin{tabular}{lc}
\hline Taxon & Abunda \\
\hline PODUROMORPHA & \\
Brachystomellidae & 139 \\
Brachystomella agrosa Wray, 1953 & 1 \\
Brachystomella sp.n.1 & \\
Hypogastruridae & 11 \\
Xenylla sp.1 & \\
Neanuridae & 28 \\
Neotropiella sp.1 & 54 \\
Neotropiella sp.2 & \\
ENTOMOBRYOMORPHA &
\end{tabular}

\section{Entomobryidae}

Lepidocyrtus nigrosetosus Folsom, $1927 \quad 25$

Lepidocyrtus sp. n.1 44

Lepidocyrtus sp. n.2 18

Seira paraibensis Bellini \& Zeppelini, $2009 \quad 47$

Seira mirianae Arlé \& Guimaraes, 1981

Seira ritae Bellini \& Zeppelini, 2011

Seira sp. n.1 41

Seira sp. n.2 55

Isotomidae

Isotomiella $\mathrm{sp.} \quad 11$

Isotomurus $\mathrm{sp.} \quad 28$

Paracerura sp. 13

Proisotoma sp. 17

Paronellidae

Trogolaphysa sp.

SYMPHYPLEONA

\section{Bourletiellidae}

gen.n.1

Stenognathriopes janssensi Zeppelini \& Silva, 2012

Dicyrtomidae

Calvatomina sp.

Sminthuridae

Temeritas sp.

233

Varelasminthurus potiguarus Silva \& Bellini, 2015

\section{Sminthurididae}

Sphaeridia heloisea

52

Sphaeridia sp.

Katiannidae

Sminthurinus sp.

Total number of individuals

2,326

Total number of species

(1)

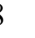

4

8


Table 2. Dung beetles collected during the rainy period (May, 2014, and April, 2015) in Serra de Santa Catarina, state of Paraíba, Brazil.

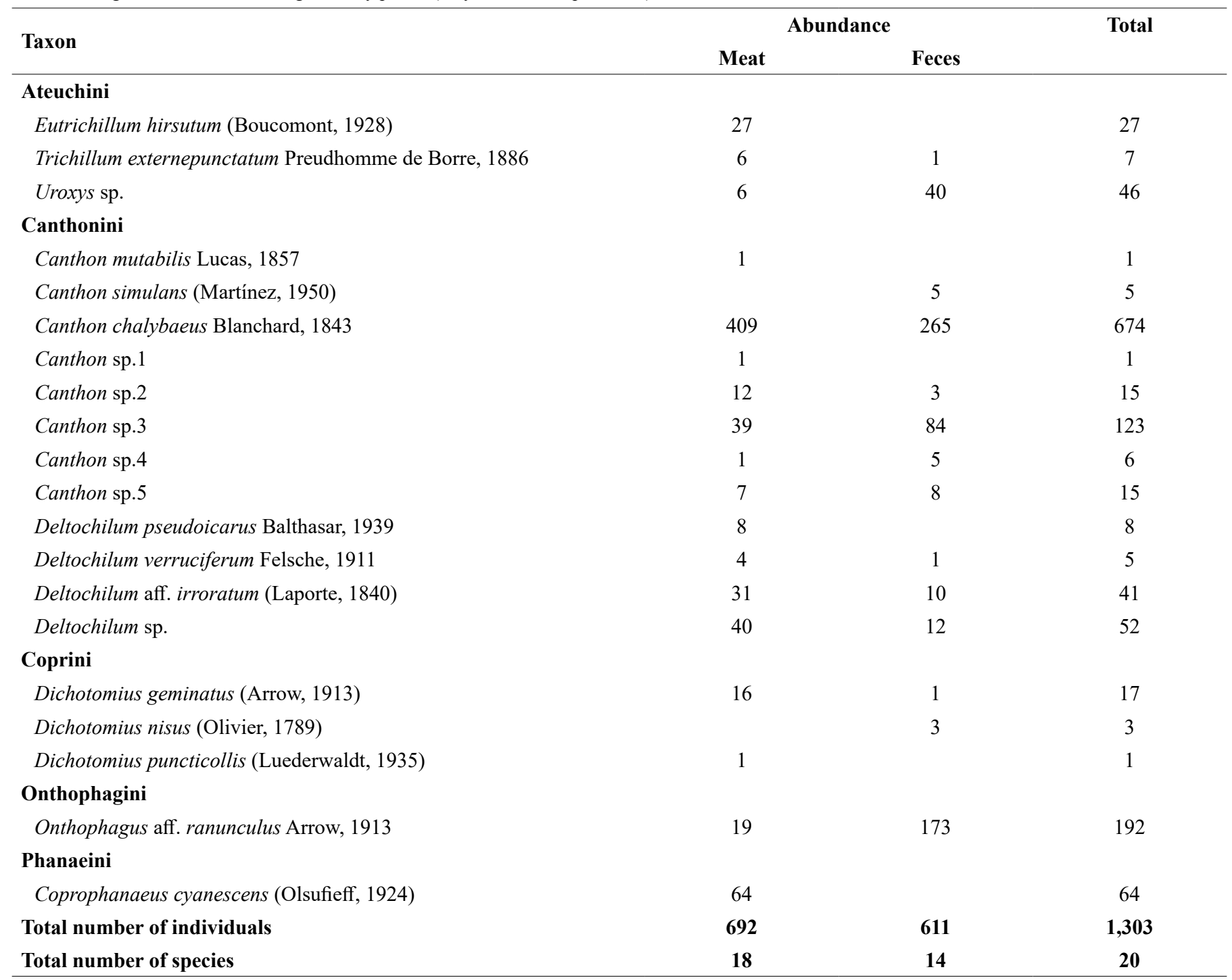

d.f. $=1 ; 38 ; \mathrm{p}=0.08$ ) among the baits; 692 specimens belonging to 18 species were found on meat and 611 specimens of 14 species were found on feces bait. However, evaluating the species composition, it was found that Coprophanaeus cyanescens and Eutrichillum sp. occurred exclusively in meat baits.

\section{Saprophagous calyptrate flies}

A total of 7,669 saprophagous flies were collected of 30 species distributed among four families (Table 3). Sarcophagidae was the richest family ( $S=15)$, followed by Calliphoridae $(S=7)$, Muscidae $(S=6)$ and Faniidae ( $\mathrm{S}=2$ ). With regard to abundance, Calliphoridae surpassed all other families with $78 \%$ of the specimens collected. According to the mean estimated species richness, $92.26 \%$ of the species of the area were sampled (Sobs=31; Sest mean=33.6) (Figure 3). Significant difference was found in abundance $(\mathrm{F}=15.864$; d.f $=3 ; 76 ; \mathrm{p}<0.0001)$ and species richness $(\mathrm{F}=140.72 ;$ d.f. $=3 ; 76 ; \mathrm{p}<0.0001)$ of saprophagous flies among the baits. There was no difference in abundance $(\mathrm{p}=0.84)$ and species richness ( $\mathrm{p}=0.83)$ between the most attractive baits, meat $(\mathrm{N}=4.150)$ and sardine $(\mathrm{N}=3.506)$. The traps baited with banana $(\mathrm{N}=7)$ and feces $(\mathrm{N}=6)$ showed little attractiveness to the studied families, showing no significant difference between abundance $(\mathrm{p}=1.00)$ and species richness $(\mathrm{p}=0.99)$.

\section{Termites}

Thirty-eight species of termites, representing 23 genera and three families, were recorded for the area (Table 4), with a total of 287 encounters. In general, the family Termitidae was the most represented both with regard to species richness (89\%), and frequency of encounters (90\%). In relation to feeding habits, consumers of wood and consumers of humus were dominant. Eight termite species construct conspicuous nests, seven of which are arboreal-type and one epigeous-type. Nests of Syntermes cearensis were abundant in the landscape of the area, and these nests represented more than $11 \%$ of all. According to the mean estimated species richness, $69.52 \%$ of the species of the area were sampled (Sobs=38; Sest mean=54.66) (Figure 3). 
Hexapod decomposers in a relictual Caatinga

Table 3. Saprophagous calyptrate flies collected during the rainy period (May, 2014, and April, 2015) in Serra de Santa Catarina, state of Paraíba, Brazil.

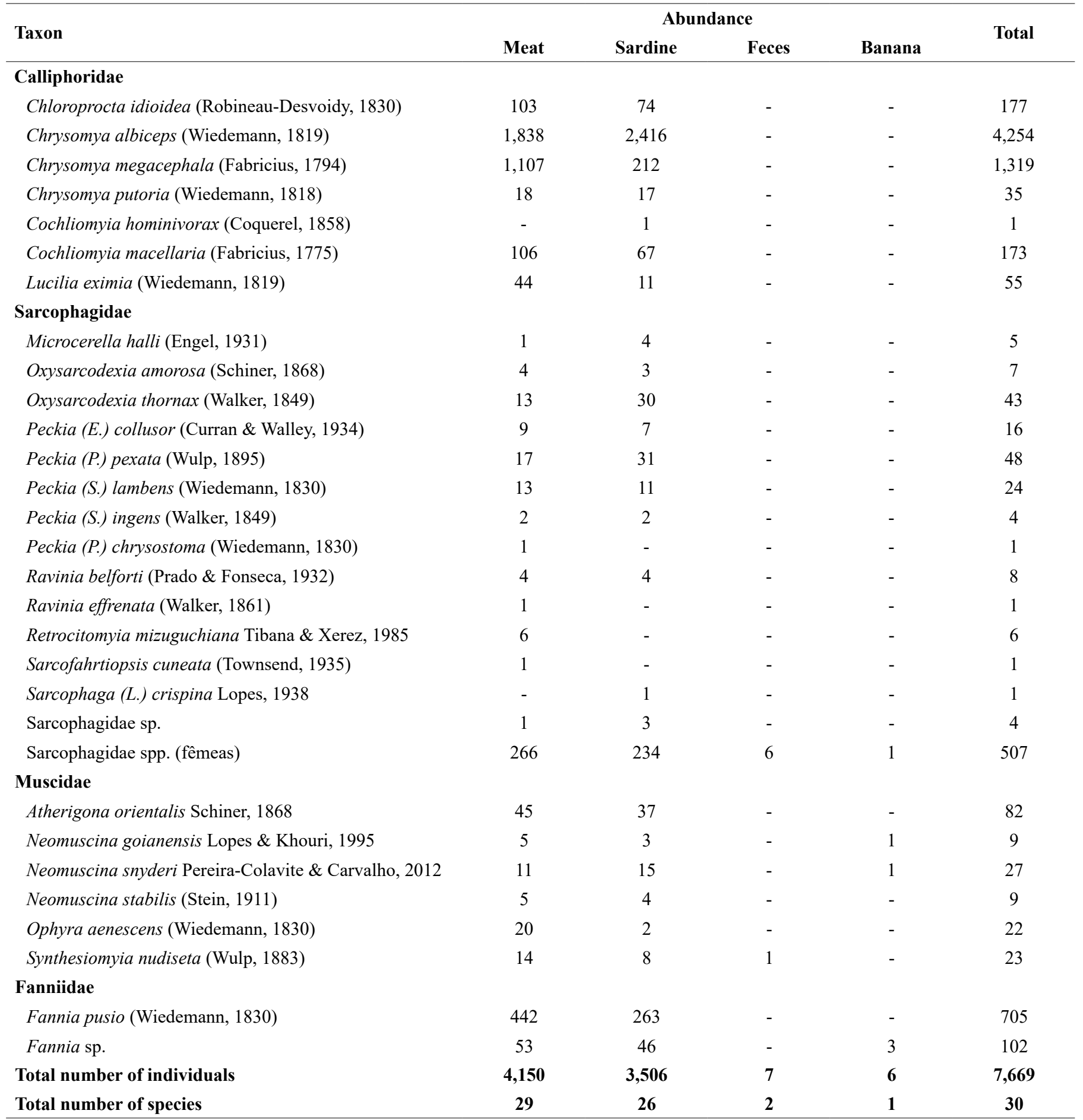


Tabela 4. Termites sampling during the rainy period (May, 2014, and April, 2015) in Serra de Santa Catarina, state of Paraíba, Brazil.

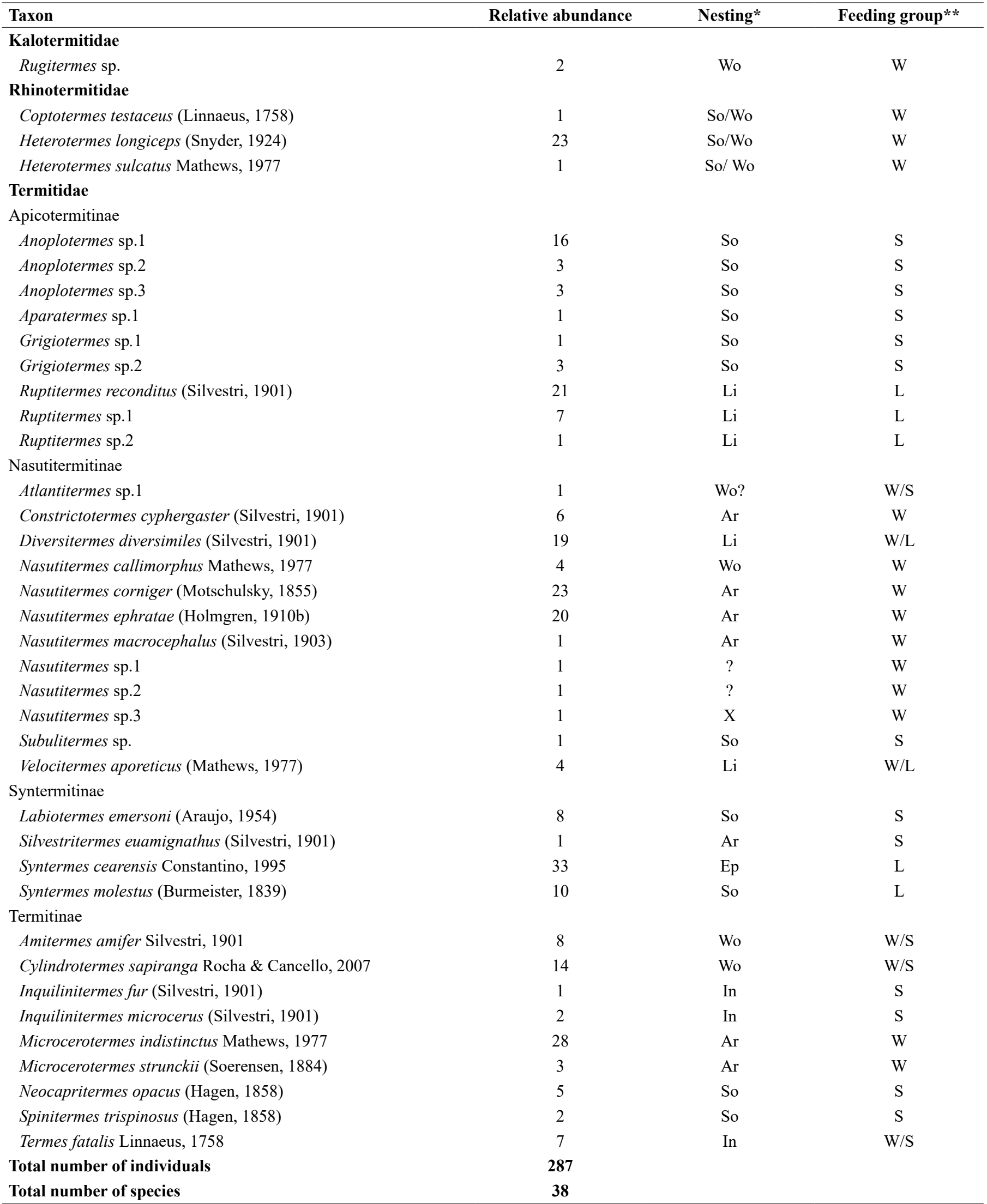

*Nesting: So, soil; Wo, wood; Li, litter; Ep, epigeous nest; Ar, arboreal nest; In, inquiline, termites which inhabit nests built by other termite species.

**Feeding groups: W, wood-feeding; S, soil-feeding; W/S, interface wood/soil-feeding; L, leaf-feeding; X/L, interface wood/leaf-feeding. 


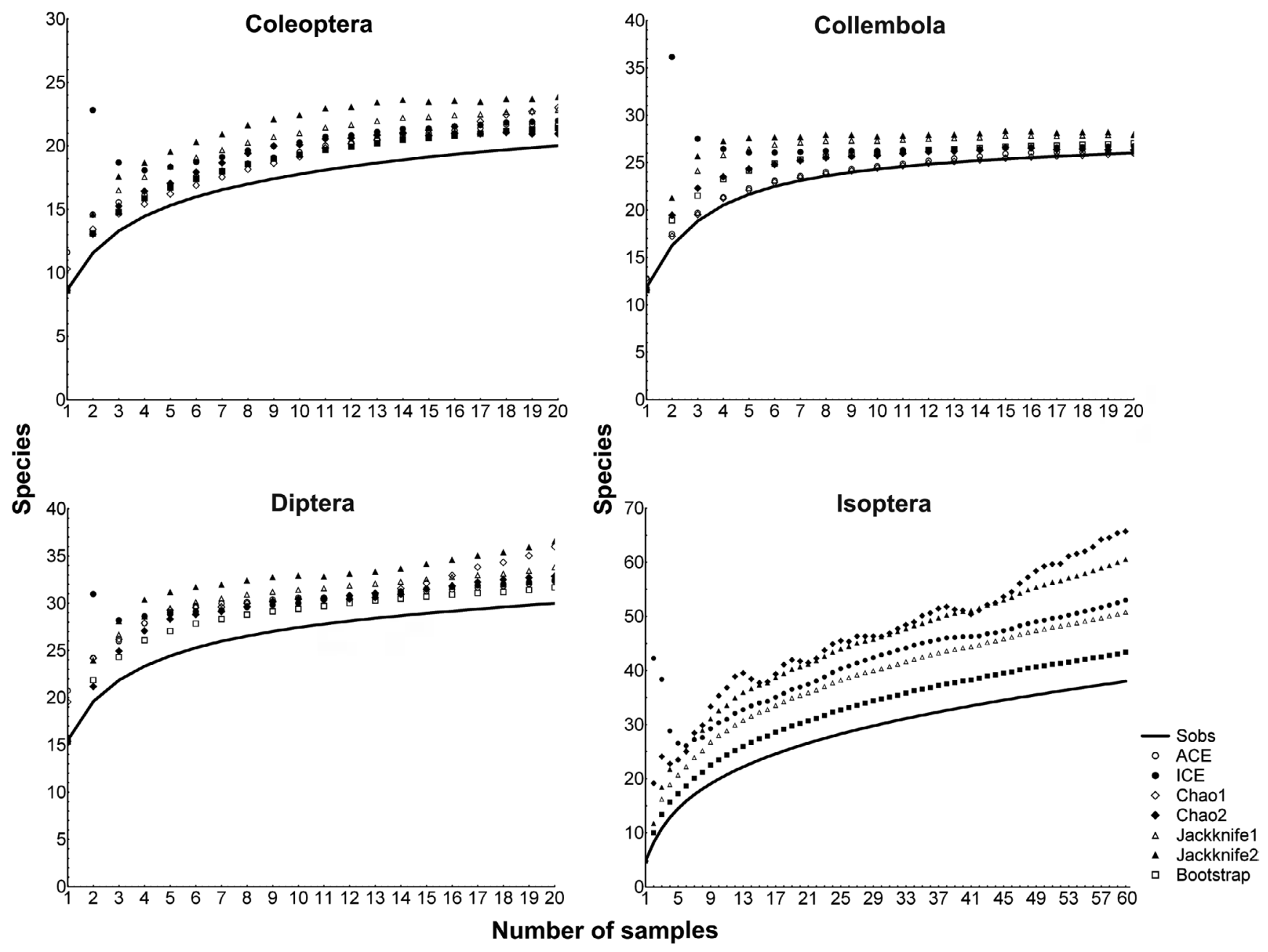

Figure 3. Species accumulation curve and the performance of estimators for each taxon. * For termites only estimators based on incidence data were analyzed (ICE, Chao2, Jackknife 1 and 2, and Bootstrap).

\section{Discussion}

According to the groups of hexapod decomposers studied, Serra de Santa Catarina stands out in terms of species richness for the Caatinga, possessing assemblages of springtails, dung beetles, saprophagous calyptrate flies and termites characteristic of a conserved area. In addition to new records for science, the species richness of springtails $(S=26)$, saprophagous flies $(S=30)$ and termites $(S=38)$ of $S S C$ are among the highest recorded for an area of Caatinga in Northeast Brazil (Vasconcellos et al. 2010, Santos-Rocha et al. 2011, Ferreira et al. 2013, Alves et al. 2014, Vasconcellos \& Moura 2014, Vasconcelos \& Salgado 2014). For the dung beetles, the total richness observed $(S=20)$ was greater or close to that found in other areas of Caatinga in Northeast Brazil ( $S=4-23)$ and identical to two other areas of Caatinga in the state of Paraíba (Hernández 2005, 2007, Lopes et al. 2006, Liberal et al. 2011, Salomão 2012, Salomão \& Iannuzzi 2017).

Species richness recorded for Collembola in the Caatinga ranges from 2 to 15 (Bellini \& Zeppelini 2009, Santos-Rocha et al. 2011, Ferreira et al. 2013), with the genus Seira being dominant with 17 species. Bellini \& Zeppelini (2009) state that the Northeast Region of Brazil is, possibly, one of the areas of greatest species richness for the genus Seira in the world. The richness of Colembolla encountered in
SSC is similar to that of the Atlantic Forest, which ranges from 17 to 25 species (Bellini \& Zeppelini 2009). Approximately 23\% of the species recorded in SSC are new to science and, if conservation measures are not adopted in the area, part of this fauna could be lost without ever being known.

Among the dung beetles, the most abundant species, Canthon chalybaeus, is found in open areas of wet forests, such as the Amazon Forest (Scheffler 2005, Silva et al. 2014) and the Atlantic Forest (Costa et al. 2009, Silva et al. 2010, Filgueiras et al. 2015), but has also been recorded in areas of Brejo de Altitude (Silva et al. 2007), Restinga (Costa et al. 2014) and Cerrado - in a area of transition with the Atlantic Forest (Durães et al. 2005). Because it is characteristic of open areas and is generally associated with humid environments (Scheffler 2005, Costa et al. 2009, 2013, 2014), this species seems to be well adapted to the peculiar conditions found in the Caatinga, such as high temperatures and low humidity, when the environment possesses well conserved forest structure. The genus Eutrichillum was recorded in this study for the first time from the Caatinga, represented by E. hirsutum. This species occurred only in the meat bait, as expected, once it usually presents a necrophagous behavior (Vaz-de-Mello 2008). This genus has a disjunct distribution, occurring in the Chaco, Paraná, Amazon sub-regions, 
Cerrado, Central America and the Caribbean (Vaz-de-Mello 2008, Andrade et al. 2011). In general, the other species recorded at SSC are widely distributed in open areas (ex.: Trichillum externepunctatum) or characteristic of the Caatinga (ex.: Deltochilum verruciferum, Dichotomius geminatus and Dichotomius puncticollis) (Lopes et al. 2006, Almeida \& Louzada 2009, Costa et al. 2009). The occurrence of Coprophanaeus cyanescens is particularly notable. This species possesses a wide distribution, being found in areas of Atlantic Forest, Brejo de Altitude, Caatinga and Cerrado, but with less abundance in the latter two environments (Lopes et al. 2006, Silva et al. 2007, Costa et al. 2009, Gillett et al. 2010, Filgueiras et al. 2015). Large-sized species, such as those of the genus Coprophanaeus, are more affected by the structure of the environment and, in general, are restricted to wellconserved forest habitats (Klein 1989, Filgueiras et al. 2011). Species of this genus are mostly necrophagous (Halffter \& Edmonds 1982) and occurred in the SSC only in the meat baits. Most of dung beetles of the $\mathrm{SSC}$ were not selective for the baits used in the present study. In relation to the resource exploitation, the feeding behavior of the dung beetle is, in general, opportunistic (Hanski and Cambefort, 1991). This trophic generality tends to decrease the competition for ephemeral and/or scarce food resources (Silva 2011) and to enhance the ability to explore the environment and to resist to the food shortage periods.

Among the calyptrate flies, the species Peckia (E.) collusor, Peckia (S.) ingens, Sarcofahrtiopsis cuneata (Sarcophagidae), Neomuscina goianensis, Neomuscina snyderi and Neomuscina stabilis (Muscidae) are recorded for the first time from the Caatinga. The absence of Musca domestica among the representatives collected of the family Muscidae, may be indicative of a good state of conservation of the area, since this species is predominantly associated with human and/or degraded environments (Carvalho et al. 2002).

The abundance of calliphorids in SSC was due to the presence of Chrysomya albiceps and Chrysomya megacephala, introduced species that are currently distributed throughout Brazil due to their considerable abilities for dispersion and acclimatization (Guimarães et al. 1979). Their establishment in the Caatinga is due to their aggressive behavior, high fecundity, dispersal capacity and short life cycle (Alves et al. 2014). These species may represent threats to populations of native species (Faria et al. 1999, Vasconcelos \& Salgado 2014), although there are no reports of competitive exclusion due to their presence in Caatinga ecosystems.

The high species richness of sarcophagids in SSC was similarly observed in other inventories carried out in a variety of different Brazilian ecosystems (Carvalho \& Linhares 2001, Barros et al. 2008, Barbosa et al. 2009, Vairo et al. 2011, Rosa et al. 2011, Vasconcelos et al. 2015). However, the species composition differs among these environments. These flies, unlike the calliphorids, seem to be more sensitive to the selective pressures of the environment, and are associated only with certain environments or climates. Studies on Sarcophagidae of the Caatinga are scarce, and the data for this family are restricted to distribution notes and species lists (Alves et al. 2014). The other studies in the Northeast are restricted to humid forests, such as the Atlantic Forest (Lopes 1974, Vasconcelos \& Araújo 2012, Vasconcelos et al. 2013, Barbosa et al. 2017).

Rotten meat and sardine showed potential for collection of these flies, evidencing the necrophilic habit of the families. D'Almeida (1992) studied the attractiveness of Muscidae and Anthomyidae using the same baits, and found that fish is the most attractive lure. Similar results were found for Calliphoridae and Sarcophagidae (d'Almeida \& Lopes 1983; d'Almeida 1984). D'Almeida e Fraga (2007) using five different baits found similar results, rotten sardine was the most attractive bait, followed by bovine liver; traps baited with fermented banana were unsuccessful in collecting flies of these families.

The species richness of termites at SSC, when compared to other areas of the Caatinga, is the greatest yet recorded for a single area (Mélo \& Bandeira 2004, Vasconcellos et al. 2010, Alves et al. 2011, Vasconcellos \& Moura 2014). Fourteen species (36\%) are of indeterminate taxonomic status, with great likelihood that they a species new to science. The average number of species estimated for the area $(S=54)$ represents $50 \%$ of the species estimated for the entire Caatinga by Vasconcellos \& Moura (2014), highlighting the potential of SSC as a priority area for the conservation of Caatinga biodiversity. Unlike other areas of Caatinga in the state of Paraíba, SSC possesses a high density ( $>20$ nests/ha) of mounds of $S$. cearenses, which has a strong influence on the formation of soils in the area. In addition, $S$. cearenses is among the largest termites in the Neotropical Region and certainly represents a conspicuous source of resources for its predators throughout the year, with peaks of supply during the rainy season when there are winged individuals.

The assemblages of springtails, dung beetles, saprophagous calyptrate flies and termites at SSC exhibited high levels of species richness when compared to other areas of the Caatinga, records of new occurrences for the domain and high potential of the occurrence of new species, demonstrating the relevance of the area for the conservation of the biodiversity of this sector of the Caatinga. These hexapod taxa are also recognized as indicators of habitat quality (Brown 1997, Ekschmitt et al. 2003, Taylor \& Doran 2004, Uehara-Prado et al. 2009), including studies conducted in the Caatinga for termites (Vasconcellos et al. 2010, Alves et al. 2011), that found the structure of their assemblages, linked to species richness, individual abundance and functional diversity, to be positively related to levels of habitat conservation. In addition, flies, dung beetles, saprophagous calyptrate flies and termites act primarily on the detritus-based trophic system, which receives inputs of dead organic matter of plant and animal origin, and the structures of its assemblages demonstrate the dynamic functioning of this system. Hexapoda are dominant on a series of ecosystem processes (Gullan \& Cranston 2008), and the high diversity found at the SSC shows the relevance of the area for biodiversity conservation. Serra de Santa Catarina is a peculiar area and represents one of the few ecosystems that still have conserved vegetation cover in the state of Paraíba. Given the continuous anthropic pressure, the SSC should be seen as a priority by initiatives to conserve the biodiversity of the Caatinga.

\section{Acknowledgments}

We thank the Tropical Forest Conservation Act (TFCA), CNPq (Processo $\mathrm{n}^{\mathrm{o}} 461875 / 2014-4$ ), and the team of the Laboratório de Ornitologia da UFPB - campus II. We also thank Josimar Guedes Bezerra, our field guide, and Luciana Iannuzzi and Fernando Z. Vaz-de-Mello, for help in identifying dung beetles. 


\section{Author Contributions}

Matilde Vasconcelos Ernesto: Substantial contribution in the concept and design of the study; Contribution to data collection; Contribution to data analysis and interpretation; Contribution to manuscript preparation and critical revision, adding intellectual content.

Carolina Nunes Liberal: Substantial contribution in the concept and design of the study; Contribution to data collection; Contribution to data analysis and interpretation; Contribution to manuscript preparation and critical revision, adding intellectual content.

Aila Soares Ferreira: Substantial contribution in the concept and design of the study; Contribution to data collection; Contribution to data analysis and interpretation; Contribution to manuscript preparation and critical revision, adding intellectual content.

Ana Claudia Firmino Alves: Contribution to data collection; Contribution to data analysis and interpretation; Contribution to manuscript preparation.

Douglas Zeppelini: Contribution to critical revision, adding intellectual content.

Antonio José Creão-Duarte: Contribution to critical revision, adding intellectual content.

Celso Feitosa Martins: Contribution to critical revision, adding intellectual content.

Alessandre Pereira-Colavite: Contribution to critical revision, adding intellectual content.

Alexandre Vasconcellos: Substantial contribution in the concept and design of the study; Contribution to data analysis and interpretation; Contribution to manuscript preparation and critical revision, adding intellectual content.

\section{Conflicts of interest}

The authors declare that they have no conflict of interest related to the publication of this manuscript.

\section{References}

ALMEIDA, S.S.P. \& LOUZADA, J.N.C. 2009. Estrutura da comunidade de Scarabaeinae (Scarabaeidae: Coleoptera) em fitofisionomias do cerrado e sua importância para a conservação. Neotrop. Entomol. 38(1): 32-43.

ALVES A.C.F, SANTOS W.E \& CREÃO-DUARTE, A.J. 2014. Diptera (Insecta) de importância forense da região Neotropical. Entomotropica 29: 77-94.

ALVARES, C.A., STAPE, J.L., SENTELHAS, P.C., GONÇALVES, J.L.M. \& SPAROVEK, G. 2013. Köppen's climate classification map for Brazil. Meteorol Z 22(6): 711-728.

ALVES, W.F., MOTA, A.S., LIMA, R.A.A., BELLEZONI, R. \& VASCONCELLOS, A. 2011. Termites as Bioindicators of Habitat Quality in the Caatinga, Brazil: Is There Agreement Between Structural Habitat Variables and the Sampled Assemblages? Neotrop. Entomol. 40: 39-46.

ANDRADE, R.B., BARLOW, J., LOUZADA, J., VAZ-DE-MELLO, F.Z., SOUZA, M., SILVEIRA, J.M. \& COCHRANE, M.A. 2011. Quantifying Responses of Dung Beetles to Fire Disturbance in Tropical Forests: The Importance of Trapping Method and Seasonality. PLoS ONE 6(10): e26208

BARboSA, T.M., CARMO, R.F.R., SILVA, L.P., SALES, R.G. \& VASCONCELOS, S. D. 2017. Diversity of Sarcosaprophagous Calyptratae (Diptera) on Sandy Beaches Exposed to Increasing Levels of Urbanization in Brazil. Environ. Entomol. 1-10.

BARBOSA R.R., MELLO-PATIU, C.A., MELLO R.P. \& QUEIROZ, M.M.C. 2009. New records of calyptrate dipterans (Fanniidae, Muscidae and Sarcophagidae) associated with the decomposition of domestic pigs in Brazil. Mem. Inst. Oswaldo Cruz 104: 923-926.
BARROS R.M., MELLO-PATIU, C.A. \& PUJOL-LUZ, J.R. 2008. Sarcophagidae (Insecta, Diptera) associados à decomposição de carcaças de Sus scrofa Linnaeus (Suidae) em área de Cerrado do Distrito Federal, Brasil. Rev. Bras. Entomol. 52: 606-609.

BELLINGER P.F., CHRISTIANSEN K.A. \& JANSSENS F. 1996-2013. Checklist of the Collembola of the world. Available from: http:// www. collembola.org. [Accessed on: 06/17/2013]

BELLINI, B.C. \& ZEPPELINI, D. 2009. First records of Collembola (Ellipura) from the State of Paraíba, Northeastern Brazil. Rev. Bras. entomol. 48: 433-596.

BRANDÃO, M.H.M., PEREIRA, M.S. \& SOUSA, P.V.P. 2009. Indicadores Paleoclimáticos no alto sertão da Paraíba. In XIII Simpósio Brasileiro de Geografia Física Aplicada, 2009, Viçosa. A Geografia Física Aplicada e as Dinâmicas de Apropriação da Natureza. Editora da UFV, Viçosa.

BROWN JR., K.S. 1997. Diversity, disturbance, and sustainable use of Neotropical forests: insects as indicators for conservation monitoring. J. Insect Conserv. 1: 25-42.

BRUSCA, R.C \& BRUSCA, G.J. 2013. Invertebrados. 2 ed. Rio de Janeiro: Guanabara Koogan.

CANCELLO, E.M.; OLIVEIRA, L.C.M.; REIS, Y.T. \& VASCONCELLOS, A. 2002. Termites diversity along the Brazilian Atlantic Forest. p. 164, Proceedings of the XIV Congress International of the IUSSI (International Union for the Study of Social (Insects), Hokkaido University, Sapporo.

CARVALHO, L.M.L. \& LINHARES, A.X. 2001. Seasonality of insect succession and pig carcass decomposition in a natural forest area in southeastern Brazil. J. Forensic Sci 46: 604-608.

CARVALHO C.J.B., MOURA, M.O. \& RIBEIRO, P.B. 2002. Chave para adultos de dípteros (Muscidae, Fanniidae, Anthomyiidae) associados ao ambiente humano no Brasil. Rev. Bras. Entomol. 46: 107-144.

CARVALHO, C.J.B., RAFAEL, J.A., COURI, M.S. \& SILVA, V.C. 2012. Diptera Linnaeus, 1758. In: Insetos do Brasil: Diversidade e Taxonomia (J.A. Rafael, G.A.R. Melo, C.J.B. Carvalho, A.S. Casari \& R. Constantino, eds.). Holos, Ribeirão Preto, p.701-744.

CASSAGNE, N., GERS, C. \& GAUQUELIN, T. 2003. Relationships between Collembola, soil chemistry and humus types in forest stands (France). Biol. Fertil. Soils. 3: 355-361.

COLEMAN, D.C., CROSSLEY Jr., D.A. \& HENDRIX, P.F. 2004. Fundaments of soil ecology. 2 ed. Elsevier Academic Press, Boston.

CORNABY, B.W. 1974. Carrion reduction by animals in constrasting tropical habitats. Biotropica 6: 51-63.

COSTA, C.M.Q., SILVA, F.A.B., FARIAS, A.M.I. \& MOURA, R.C. 2009. Diversidade de Scarabaeinae (Coleoptera, Scarabaeidae) coletados com armadilha de interceptação de vôo no Refúgio Ecológico Charles Darwin, Igarassu-PE, Brasil. Rev. Bras. Entomol. 53: 88-94.

COSTA, F.C., PESSOA, K.K.T., SALOMÃO, R.P., LIBERAL, C.N., FILGUEIRAS, B.K.C. \& IANNUZZI, L. 2013. What is the importance of open habitat in a predominantly closed forest to the dung beetle community? Rev. Bras. Entomol. 57: 329-334.

COSTA, C.M.Q., BARRETTO, J.W. \& MOURA, R.C. 2014. Changes in the dung beetle community in response to restinga forest degradation. J. Insect Conserv. 18: 895-902.

COLWELL, R. K. 2016. EstimateS: Statistical estimation of species richness and shared species from samples. Version 9.1.0 Persistent URL < viceroy. colorado.edu/estimates/>

D’ALMEIDA, J.M. 1984. Sinantropia de Sarcophagidae (Diptera) na região metropolitana do Estado do Rio de Janeiro. Arq. Univ. Fed. Rural Rio de Janeiro 7: 101-110.

D’ ALMEIDA J.M. 1992. Calyptrate Diptera (Muscidae) and Anthomyiidae of the State of Rio de Janeiro - I. Synanthropy. Mem. Inst. Oswaldo Cruz 87: 381-386.

D'ALMEIDA, J.M. \& LOPES, H.S. 1983. Sinantropia de dípteros caliptrados (Calliphoridae) no Estado do Rio de Janeiro. Arq. Univ. Fed. Rural 6: 39-48.

D'ALMEIDA, M. J. \& FRAGA, M.B. 2007. Efeito de diferentes iscas na atração de califorídeos (Diptera) no Campus do Valonguinho, Universidade Federal Fluminense, Niterói, RJ, Brasil. Rev. Bras. Parasitol. Vet. 16: 199-204. 
DURÃES, R., MARTINS, W.P. \& VAZ-DE-MELLO, F.Z. 2005. Ecology, behavior and bionomics dung beetle (Coleoptera: Scarabaeidae) assemblages across a natural forest-cerrado ecotone in Minas Gerais, Brazil. Neotrop. Entomol. 34: 1-11.

EKSCHMITT, K., STIERHOFF, T.H., DAUBER, J., KREIMES, K. \& WOLTERS, V. 2003. On the quality of soil biodiversity indicators: abiotic and biotic parameters as predictors of soil faunal richness at different spatial scales. Agric. Ecosyst. Environ. 98: 273-283.

FARIA, L.D.B, ORSI, L., TRINCA, L.A. \& GODOY, W.A.C. 1999. Larval predation by Chrysomya albiceps on Cochliomyia macellaria, Chrysomya megacephala and Chrysomya putoria. Entomol. Exp. Appl. 90: 149-155.

FAVILA, M.E. \& HALFFTER, G. 1997 The use of indicator groups for measuring biodiversity as related to community structure and function. Acta Zool. Mex. (n.s.) 72: 1-25.

FERREIRA, A.S., BELLINI, B.C. \& VASCONCELLOS, A. 2013. Temporal variations of Collembola (Arthropoda: Hexapoda) in the semiarid Caatinga in northeastern Brazil. Zoologia (Curitiba) 30(6): 639-644.

FILGUEIRAS, B.K.C., IANNUZZI, L. \& LEAL, I.R. 2011. Habitat fragmentation alters the structure of dung beetle communities in the Atlantic Forest. Biol. Conserv. 144: 362-369.

FILGUEIRAS, B.K.C., TABARELLI, M., LEAL, I.R., VAZ-DE-MELLO, F. Z. \& IANNUZZI, L. 2015. Dung beetle persistence in human-modified landscapes: combining indicator species with anthropogenic land use and fragmentation-related effects. Ecol. Indic. 55: 65-73.

GILLETT, C.P.D.T., GILLETT, M.P.T., GILLETT, J.E.D.T. \& VAZ-DE-MELLO, F.Z. 2010. Diversity and distribution of the scarab beetle tribe Phanaeini in the northern states of the Brazilian Northeast (Coleoptera: Scarabaeidae: Scarabaeinae). Insecta Mundi 0118: 1-19.

GUIMARÃES, J.H., PRADO, A.P. \& BURALLI, G.M. 1979. Dispersal and distribution of the three newly introduced species of Chrysomya RobineauDesvoidy in Brazil (Diptera: Calliphoridae). Rev. Bras. Entomol. 23: 245-255.

GULLAN, P.J. \& CRANSTON, P.S. 2008. Os insetos: um resumo de entomologia. 7 ed. Roca, São Paulo.

HALFFTER, G. 1991. Historical and ecological factors determining the geographical distribution of beetles (Coleoptera: Scarabaeidae: Scarabaeinae). Folia Entomol. Mex. 82: 195-238

HALFFTER, G. \& EDMONDS, W.D. 1982. The nesting behaviour of dung beetles (Scarabaeinae): an ecological and evolutive approach. Instituto de Ecologia, México D.F. p. 182.

HANSKI, I.; CAMBEFORT, Y. 1991. Dung beetle ecology. Princeton University Press, Princeton, New Jersey. 481p.

HERNÁNDEZ, M.I.M. 2005. Artrópodes: Besouros Scarabaeidae (Coleoptera) da área do Curimataú, Paraíba. In: Análise das Variações da Biodiversidade do Bioma Caatinga para suporte a Estratégias Regionais de Conservação (F.S. ARAÚJO, M.J.N. RODAL, M.R.V. BARBOSA, Orgs.). Ministério do Meio Ambiente, Brasília, v. 1, p.369-380.

HERNÁNDEZ, M.I.M. 2007. Besouros escarabeíneos (Coleoptera: Scarabaeidae) da Caatinga paraibana, Brasil. Oecol. Bras. 11: 356-364.

IBGE - Instituto Brasileiro de Geografia e Estatística. 2012. Manuais técnicos em geociências: Manual Técnico da Vegetação Brasileira. 2 ed. Rio de Janeiro.

KLEIN, B.C. 1989. Effects of forest fragmentation on dung and carrion beetle communities in Central Amazonia. Ecology 70: 1715-1725.

KRISHNA, K., GRIMALDI, D.A., KRISHNA, V. \& ENGEL, M.S. 2013. Treatise on the Isoptera of the world. Bull. Am. Mus. Nat. Hist. 377: 1-2704.

LAVELLE, P. \& SPAIN, A.V. 2005. Soil Ecology. Springer, Dordrecht.

LEAL, I.R., SILVA, J.M.C., TABARELLI, M. \& LACHER, J.R.T.E. 2005. Changing the course of biodiversity conservation in the caatinga of northeastern Brazil. Conserv. Biol. 19(3): 701-706.

LEIVAS, F.W.T \& CARNEIRO, E. 2012. Utilizando os hexápodes (Arthropoda, Hexapoda) como bioindicadores na Biologia da Conservação: Avanços e perspectivas. Estud. Biol., Ambiente Divers. 34(83): 203-213.
LIBERAL, C. N., FARIAS, A. M. I., MEIADO, M. V., FILGUEIRAS, B. K. C. \& IANNUZZI, L. 2011. How habitat change and rainfall affect dung beetle diversity in Caatinga, a Brazilian semi-arid ecosystem? J. Insect Sci. 11: 1-11.

LOPES, H.S. 1974. Sarcophagid flies Diptera from Pacatuba, State of Ceará, Brazil. Rev. Bras. Biol. 34(2): 271-294.

LOPES, P.P., LOUZADA, J. \& VAZ-DE-MELLO, F.Z. 2006. Organization of dung beetle communities (Coleoptera, Scarabaeidae) in areas of vegetation re-establishment in Feira de Santana, Bahia, Brazil. Sitientibus Ser. Ci. Biol. 6: 261-266.

MÉLO, A.C.S. \& BANDEIRA, A.G. 2004. A Qualitative and Quantitative Survey of Termites (Isoptera) in an Open Shrubby Caatinga in Northeast Brazil. Sociobiol. 44: 707-716.

MILHOMEM, M.S.; VAZ-DE-MELLO, F.Z. \& DINIZ, I.R. 2003. Técnicas de coleta de besouros copronecrófagos no Cerrado. Pesq. Agropec. Bras. 38(11): 1249-1256.

PORTILLO-QUINTERO, C.A. \& SÁNCHEZ-AZOFEIFA, G.A. 2010. Extent and conservation of tropical dry forests in the Americas. Biol. Conserv. 143:144-155.

QUERNER, P. \& BRUCKNER, A. 2010. Combining pitfall traps and soil samples to collect Collembola for site scale biodiversity assessments. Appl. Soil Ecol. 45: 293-297.

ROSA T.A., BABATA, M.L.Y., SOUZA, C.M., SOUSA, D., MELLO-PATIU, C.A., VAZ-DE-MELLO, F.Z. \& MENDES, J. 2011. Arthropods associated with pig carrion in two vegetation profiles of Cerrado in the State of Minas Gerais, Brazil. Rev. Bras. Entomol. 55: 424-434.

SALOMÃO, R. P. 2012. Período de atividade de besouros (Coleoptera) copronecrófagos em um ambiente semiárido do Nordeste brasileiro. In Ecologia da Caatinga curso de campo 2012 (J.D. RIBEIRO NETO, F.M.P. OLIVEIRA, E.A.E.S. SILVA, I. LEAL, F. MELO, M. TABARELLI, \& D.G. SOUZA orgs.). Editora Universitária UFPE, Recife, p.490-499.

SALOMÃO, R.P. AND IANNUZZI, L. 2017. How Do Regeneration Stages of Caatinga Forests Influence the Structure of Dung Beetle (Coleoptera: Scarabaeidae) Assemblage? Coleopt. Bull. 71(3): 578-588.

SANTOS, J.C., LEAL, I.R., ALMEIDA-CORTEZ, J.S., FERNANDES, G.W. \& TABARELLI, M. 2011. Caatinga: the scientific negligence experienced by a dry tropical forest. Trop. Conserv. Sci. 4(3): 276-286.

SANTOS-ROCHA I.M., ANDREAZZE R. \& BELLINI B.C. 2011. Registros de Collembola (Arthropoda, Hexapoda) no estado do Rio Grande do Norte, Brasil. Biota Neotrop. 11(3): 167-170. http://www.biotaneotropica.org.br/ v11n3/en/abstract?article+bn02611032011 (último acesso em 15/03/2017).

SÄRKINEN, T., IGANCI, J.R.V., LINARES-PALOMINO, R., SIMON, M.F.\& PRADO, D.E. 2011. Forgotten forests - issues and prospects in biome mapping using Seasonally Dry Tropical Forests as a case study. BMC Ecology 11: 27

SCHEFFLER, P. 2005. Dung beetle (Coleoptera: Scarabaeidae) diversity and community structure across three disturbance regimes in eastern Amazonia. J. Trop. Ecol. 21: 9-19.

SILVA, P. G. 2011. Dung beetles (Coleoptera: Scarabaeidae: Scarabaeinae) of two non-native habitats in Bagé, Rio Grande do Sul, Brazil. Zool. Stud. 50: 546-559.

SILVA, F.A.B., HERNÁNDEZ, M.I.M., IDE, S. \& MOURA, R.C. 2007. Comunidade de escarabeíneos (Coleoptera, Scarabaeidae) copro-necrófagos da região de Brejo Novo, Caruaru, Pernambuco, Brasil. Rev. Bras. Entomol. 51: 228-233.

SILVA, F.A.B.; COSTA, C.M. Q.; MOURA, R.C. \& FARIAS, A.M.I. 2010. Study of the Dung Beetle (Coleoptera: Scarabaeidae) Community at Two Sites: Atlantic Forest and Clear-Cut, Pernambuco, Brazil. Environ. Entomol. 39: 359-367.

SILVA, R.J., COLETTI, F., COSTA, D.A. \& VAZ-DE-MELLO, F.Z. 2014. Rolabostas (Coleoptera: Scarabaeidae: Scarabaeinae) de florestas e pastagens no sudoeste da Amazônia brasileira: Levantamento de espécies e guildas alimentares. Acta Amaz. 44(3): 345 - 352. 
SOUSA, P.V.P. 2011.A Serra de Santa Catarina: um enclave subúmido no sertão paraibano e a proposta de criação de uma unidade de conservação. Dissertação de Mestrado em Geografia. Universidade Federal do Ceará, Fortaleza.

SOUZA, A.M. \& LINHARES, A.X. 1997. Diptera and Coleoptera of potential forensic importance in southeastern Brazil: relative abundance and seasonality. Med. Vet. Entomol. 11: 8-12.

STATSOFT, I. 2007. STATISTICA (data analysis software system), version 8.0. www.statsoft.com

TARASOV, S. \& GÉNIER, F. 2015. Innovative Bayesian and Parsimony Phylogeny of Dung Beetles (Coleoptera, Scarabaeidae, Scarabaeinae) Enhanced by Ontology-Based Partitioning of Morphological Characters. PLoS ONE 10(3): e0116671.

TAYLOR, N. \& DORAN, N. 2004. Identification of species and functional groups that give early warning of major environmental change (Indicator 1.2c). Part D: Use of terrestrial invertebrates as indicators of the ecological sustainability of forest management under the Montreal Process. Australian Government. Forest and Wood Products Research and Development Corporation.

UEHARA-PRADO, M., FERNANDES, J.O., BELLO, A.M., MACHADO, G., SANTOS, A.J., VAZ-DE-MELLO, F.Z. \& FREITAS, A.V.L. 2009. Selecting terrestrial arthropods as indicators of small-scale disturbance: A first approach in the Brazilian Atlantic Forest. Biol. Conserv. 142: 1220- 1228.

VAIRO K.P., MELLO-PATIU, C.A. \& CARVALHO, C.J.B. 2011. Pictorial identification key for species of Sarcophagidae (Diptera) of potential forensic importance in southern Brazil. Rev. Bras. Entomol. 55: 333-347.
VASCONCELLOS, A. 2010. Biomass and abundance of termites in three remanant areas of Atlantic Forest in northeastern Brazi. Rev. Bras. Entomol 54(3), 455-461.

VASCONCELLOS, A. \& MOURA, F.M.S. 2014. Térmitas de Oito Ecossistemas Inseridos no Domínio do Semiárido Brasileiro. In: Artrópodes do Semiárido: Biodiversidade e Conservação (F. BRAVO \& A. CALOR, orgs.). Printmídia, Feira de Santana, p. 99-109.

VASCONCELLOS, A., BANDEIRA, A.G., MOURA, F.M.S., ARAÚJO, V.F.P., GUSMÃO, M.A.B. \& CONSTANTINO, R. 2010. Termite Assemblages in Three Habitats under Different Disturbance Regimes in the Semi-Arid Caatinga of Ne Brazil. J. Arid Environ. 74: 298-302.

VASCONCELOS, S.D. \& ARAUJO M.S.C. 2012. Necrophagous Diptera and Coleoptera in Northeastern Brazil: State of the art and challenges for the forensic entomologist. Rev. Bras. Entomol. 56(1): 7-14.

VASCONCELOS, S.D., BARBOSA, T.M. \& OLIVEIRA, T.P.B. 2015. Diversity of forensically-important dipteran species in different environments in Northeastern Brazil, with notes on the attractiveness of animal baits. Fla Entomol. 98: 770-775.

VASCONCELOS S.D, CRUZ T.M., SALGADO R.L. \& THYSSEN P.J. 2013. Dipterans associated with a decomposing animal carcass in a rainforest fragment in Brazil: Notes on the early arrival and colonization by necrophagous species. J. Insect Sci. 13(145): 1-11.

VASCONCELOS S.D. \& SALGADO, R.L. 2014. First record of six Calliphoridae (Diptera) species in a seasonally dry tropical forest in Brazil: evidence for the establishment of invasive species. Fla. Entomol. 97: 814-816.

VAZ-DE-MELLO, F. Z. 2008. Synopsis of the new subtribe Scatimina (Coleoptera: Scarabaeidae: Scarabaeinae: Ateuchini), with descriptions of twelve new genera and review of Genieridium, new genus. Zootaxa 1955: $1-75$ 